\title{
A Molecular Defect in Thrombasthenic Platelets
}

\author{
L. Degos, A. Dautigny, J. C. Brouet, M. Colombani, N. Ardalllou, \\ J. P. Caen, and J. Colombani \\ From the Laboratories of Immunohematology and Immunochemistry, Institut \\ National de la Sante et de la Recherche Medicale and the Laboratory of \\ Hemostasis and Experimental Thrombosis, Hôpital St-Louis, Paris, France: the \\ Laboratory of Protein Biochemistry, Faculté de Medecine, Paris, France; and \\ the Institut de Pathologie Cellulaire, Hôpital Bicetre, Le Kremlin Bicetre, France
}

A в S T R A C T An IgG antibody found in the serum of a thrombasthenic patient reacted in complement fixation with platelets from 350 normal individuals but was nonreactive with platelets from eight other thrombasthenic patients. ADP-induced aggregation of normal platelets was inhibited by the patient's antibody. Family studies using the quantitative complement fixation test showed that healthy heterozygotes were easily distinquishable from normal or thrombasthenic individuals since their platelets had an intermediate amount of the reactive antigen. Indirect immunoprecipitation tests using this serum and soluble membrane antigens labeled with iodine-125 that had been extracted from normal platelets by the detergent Nonidet P-40 gave a single radioactive peak at $120,000 \mathrm{~mol} \mathrm{wt}$ in sodium dodecyl sulfate polyacrylamide gel electrophoresis. A similar estimate of the molecular weight was obtained from Sephadex G-200 filtration of the soluble antigens extracted from normal platelets by spontaneous release or chaotropic agents and tested in complement fixation with the patient's serum.

These findings strongly suggest that the molecule recognized by this antibody is absent or structurally modified in thrombasthenia cases and that it may be involved in platelet aggregation.

\section{INTRODUCTION}

Thrombasthenia is an inherited bleeding disorder (1) characterized by the failure of platelets to aggregate after various stimuli such as $\operatorname{ADP}(2,3)$. This disorder is transmitted as a recessive autosomal trait. Presumed heterozygous individuals have neither abnormal bleeding tendencies nor defective platelet aggregation. Various abnormalities have been described in this disease (4), and one report suggests that there

Received for publication 23 January 1975 and in revised form 24 March 1975. is an unusual pattern of membrane platelet glycoprotein (5).

We have had the opportunity of studying the serum of a thrombasthenic patient which reacts with all normal platelets tested but not with thrombasthenic platelets. This report deals with the characterization of the antigen involved and with family studies showing a defect in healthy heterozygous individuals.

\section{METHODS}

Patient $\mathrm{L}$ had the classical features of thrombasthenia and suffered mainly from intestinal bleeding. Diagnosis was established by prolonged bleeding time, impaired clot retraction, and the complete failure of platelets to aggregate either spontaneously or after incubation with ADP. No other coagulation defects were found, and the number and morphology of the platelets were normal. At the time of the study the patient had received no transfusions for 2 $\mathrm{yr}$, but $9 \times 10^{10}$ of his sister's platelets were infused to study their survival and to determine the efficiency of platelet transfusion before major surgery. The sample of serum $L$ under study was obtained 15 days after this infusion.

Platelets were obtained by differential centrifugation at $4^{\circ} \mathrm{C}$ of blood taken into plastic tubes on disodium EDTA at a final concentration of $0.5 \%$. They were washed three times and stored at $4^{\circ} \mathrm{C}$ at a concentration of $2 \times 10^{\circ} / \mu 1$ in plain saline containing $0.1 \%$ sodium azide.

Qualitative complement fixation (6). $2 \mu \mathrm{l}$ platelets at a concentration of $5 \times 10^{5} / \mu 1,2 \mu 1$ of diluted test serum, and $2 \mu 1$ human complement (C) ${ }^{1}$ corresponding to two $100 \%$ haemolytic units $(\mathrm{CH} 100)$ were placed in each well of a nonwettable microplate (C. A. Greiner und Söhne, West Germany) under mineral oil. After mixing and incubation for $1 \mathrm{~h}$ at $37^{\circ} \mathrm{C}, 2 \mu \mathrm{l}$ of sensitized sheep erythrocytes at a concentration of $2 \times 10^{5} / \mu 1$ were added. After further incubation for $30 \mathrm{~min}$ at $37^{\circ} \mathrm{C}$ the plates wert centrifuged, and the presence or absence of haemolysis was checked.

Quantitative complement microtechnique (7). This assay is similar to the qualitative one, but different concentrations of platelets $\left(1-6 \times 10^{5} /\right.$ test $)$ and of guinea pig complement (1-10 CH100 U) were used. For each platelet concentration the number of $\mathrm{C}$ units fixed was recorded.

${ }^{1}$ Abbreviations used in this paper: C, complement; D, last dilution; $\mathrm{V}$, volume of extract. 
Detection of blocking antibodies (8). $3 \times 10^{7}$ platelets were incubated with $60 \mu \mathrm{l}$ of normal or pathological blocking serum for $1 \mathrm{~h}$ at $37^{\circ} \mathrm{C}$. After washing the platelets were resuspended in $100 \mu 1$ of veronal-buffered saline $(\mathrm{pH} 7.3)$. $2 \mu \mathrm{l}$ of this platelet suspension, $2 \mu \mathrm{l}$ of complement-fixing serum L, and $2 \mu \mathrm{l}$ of guinea-pig complement (1-10 CH100 $\mathrm{U})$ were distributed in microplates and treated as above. Blocking antibodies were considered to be present when the C fixation was significantly inhibited by pretreatment of the platelets by the pathological serum: more than $1.5 \mathrm{C}$ $\mathrm{U}$ difference when compared to $\mathrm{C}$ fixation with platelets pretreated with normal serum.

Fixing activity of soluble antigens. The number of units with fixing activity was calculated from the volume of the extract (V) in microliters and the last dilution (D) of this solution which gives $50 \%$ haemolysis. Serum L was taken at a standard dilution $(1: 5)$. Fixing activity is equal to the product of $\mathrm{V}$ with the inverse of $\mathrm{D}$.

Elution of specific antibodies from $30 \times 10^{9}$ normal platelets previously sensitized with $3 \mathrm{ml}$ of serum L was performed at $\mathrm{pH} 3$ (9). The volume of eluate obtained was 1.5 $\mathrm{ml}$.

Inhibition of platelet aggregation. Aggregation was estimated using Born's photometric method (10). $0.2 \mathrm{ml}$ of platelet-rich plasma was added to $20 \mu 1$ of eluate $\mathrm{L}$ (1 $\mathrm{mg} \mathrm{IgG} / \mathrm{ml}$ ) at various dilutions and aggregation was induced by $10 \mu 1$ of ADP (final concentration: $10 \mu \mathrm{mol}$ ) or by thrombin, collagen, epinephrine, and ristocetin.

Preparation of soluble membrane antigens. These antigens were obtained either by spontaneous release from platelets stored at $4^{\circ} \mathrm{C}$ for 8 days to 6 mo or by extraction with chaotropic agents. Extraction with lithium chloride was adapted from Marchesi and Andrews' method (11). Crude membranes were first incubated for $10 \mathrm{~min}$ with $0.3 \mathrm{M}$ lithium chloride (Prolabo, Paris, France) in $0.05 \mathrm{M}$ Tris-

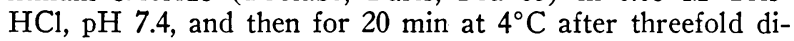
lution. Extraction with $3 \mathrm{M}$ potassium chloride was done using the method of solubilizing HL-A antigens from lymphoid cells in culture (12). In both cases soluble extracts were obtained by centrifugation for $90 \mathrm{~min}$ at $165,000 \mathrm{~g}$, dialysis against a Tris- $\mathrm{HCl}$ buffer, $0.05 \mathrm{M}, \mathrm{pH} 7.4$, containing 0.15 $\mathrm{M} \mathrm{NaCl}$, and concentration on Amicon PM 10 membrane.

Indirect immunoprecipitation of soluble antigens (13). The labeling of platelet surfaces with iodine- 125 by the lactoperoxidase method was performed as previously described by Marchalonis (14). Soluble antigens were obtained by extraction with the detergent Nonidet P-40 (Shell Chemical Co., New York) at a final concentration of $0.5 \%$ (vol/ vol) (15) in a Tris- $\mathrm{HCl}$ buffer, $0.05 \mathrm{M}, \mathrm{pH} 7.4$, containing $0.15 \mathrm{M} \mathrm{NaCl}$ and centrifuged for $90 \mathrm{~min}$ at $165,000 \mathrm{~g} .31 \%$ of the platelet radioactivity was recovered by this process.

$60-\mu 1$ samples of a $10-\mathrm{ml}$ preparation of soluble antigens obtained from $100 \times 10^{\circ}$ platelets were indubated with $20 \mu 1$ of serum or eluate $\mathrm{L}$ ( 10 and $1 \mathrm{mg}$ of $\mathrm{IgG}$ per $\mathrm{ml}$, respectively) for $1 \mathrm{~h}$ at $22^{\circ} \mathrm{C}$ and precipitated with excess rabbit antihuman $\operatorname{IgG}\left(1 \mathrm{~h}\right.$ at $37^{\circ} \mathrm{C}$ and $24 \mathrm{~h}$ at $\left.4^{\circ} \mathrm{C}\right)$. The precipitate was washed three times. Preliminary indirect immunoprecipitation curves with serum or eluate $L$ were performed to determine $(a)$ the ratio of anti-IgG antibodies to serum (or eluate) $\mathrm{L}$, and $(b)$ the ratio of serum to labeled antigens that gave the maximum precipitate and ensured total IgG precipitation. No residual antiplatelet activity was found in the supernates.

Molecular weight determination. The precipitate was dissolved in $1 \%$ sodium dodecyl sulfate, boiled for $3 \mathrm{~min}$, and submitted to electrophoresis in $10 \%$ polyacrylamide gel in the presence of $0.1 \%$ sodium dodecyl sulfate in an elec- trode buffer of $\mathrm{pH} 8.3$ (16). Bovine serum albumin $(69,000$ mol wt; Sigma Chemical Co., St. Louis, Mo.), human IgG (160,000 mol wt; Miles Chemical Co., Elkhart, Ind.), and chicken lysozyme (14,600 mol wt; Serva, Heidelberg, West Germany) were used as molecular weight markers. The gel was frozen in dry-ice and cut into $2-\mathrm{mm}$ slices. Radioactivity was calculated using a gamma ray counter (Intertechnique, France). The controls included normal serum or suitable anti-HL-A serum instead of serum 1.

Sephadex G-200 filtration of soluble antigens in a Tris$\mathrm{HCl}$ buffer, $0.05 \mathrm{M}, \mathrm{pH} 7.4$, containing $0.15 \mathrm{M} \mathrm{NaCl}$ was performed on a column of $12 \times 0.9 \mathrm{~cm}$ calibrated with the molecular weight markers used above. The elution volume of the molecule reacting with serum $\mathrm{L}$ was determined by direct complement fixation with serum $\mathrm{L}$, and that of the HL-A molecule was determined by inhibition of complement fixation with suitable anti-HL-A antibodies.

\section{RESULTS}

The complement fixation reaction with serum or eluate $\mathrm{L}$ and platelets from 350 healthy unrelated individuals was invariably positive to a dilution of $1: 25$. The results were constantly negative when platelets of eight other thrombasthenic patients were tested, as well as with the serum donor's own platelets.

Another sample of the patient's serum, taken 6 mo after that studied, showed a weak reactivity by complement fixation on normal platelets (up to a dilution of $1: 5)$. Blocking antibodies were readily apparent $(2 \mathrm{CH} 100 \mathrm{U})$. It is interesting to note that a serum sample taken $1 \mathrm{yr}$ before the platelet infusion contained blocking antibodies (2 $\mathrm{CH} 100 \mathrm{U})$ but no complementfixing antibodies. This finding is consistent with the shortened survival time (less than $24 \mathrm{~h}$ ) of sister's platelets.

The eluates obtained from normal platelets sensitized only with serum L contained IgG antibodies with $\kappa$ and $\lambda$ chains as shown by double diffusion experiments.

No positive reaction could be detected by lymphocytotoxicity or by complement fixation on lymphocytes (150 normal individuals) or on five different cultured lymphoblastoid cells. Moreover, the absorption of serum $\mathrm{L}$ by normal lymphocytes did not modify the reaction with normal platelets. These findings together with the repeated absence of reaction with platelets from thrombasthenic patients possessing 17 different HL-A specificities excluded the possibility that an anti-HL-A antibody was involved in the reactivity of serum L. The complement fixation reaction was also positive on platelets from five $\mathrm{Pl}^{\mathrm{\Lambda 1}(-)}$ and two $\mathrm{Pl}^{\mathrm{E} 1(-)}$ individuals, showing that serum $\mathrm{L}$ did not recognize $\mathrm{P}^{1^{11}}$ or $\mathrm{Pl}^{\mathrm{E}^{1}}$ antigens. The antigenic determinant was detected with the eluate $L$ on platelets from dogs and mice.

The quantitative fixation test performed on normal platelets showed an increased amount of antigenic reactivity as they aged. Using $3 \times 10^{5}$ platelets per test, 
one, four, and eight complement units were fixed on days 0,2 , and 4 , respectively. A plateau was reached on day 4 and remained stable for more than $6 \mathrm{mo}$. Platelets from the eight thrombasthenic patients showed a total lack of reactivity no matter what their age (Fig. 1).

Similar studies were performed in three different thrombasthenic families. The complement fixation curves for the presumably heterozygous relations of patient $L$ (both parents and one child) showed a reactivity pattern midway between that of the patient and that of normal individuals (Fig. 1). In a second family two children were affected. The two parents and a sibling had intermediate patterns, whereas another sibling was normal. In a third family, only the patient's mother was tested. She also showed an intermediate pattern. All thrombasthenic platelets reacted normally in the complement fixation test with antiHL-A antibodies.

The direct complement fixation test could detect the antigenic determinant on solubilized membrane antigens. Soluble antigens were obtained from whole platelets or from crude membranes either by spontaneous release or by chaotropic agents. The antigenic yield was measured by its $\mathrm{C}$ fixing activity. The highest yield (25,000 U of fixing activity for $20 \times 10^{\circ}$ platelets) was obtained using lithium chloride. When potassium chloride or spontaneous release were used, the yield was $12,500 \mathrm{U}$ and $5,000 \mathrm{U}$, respectively, for the same number of platelets.

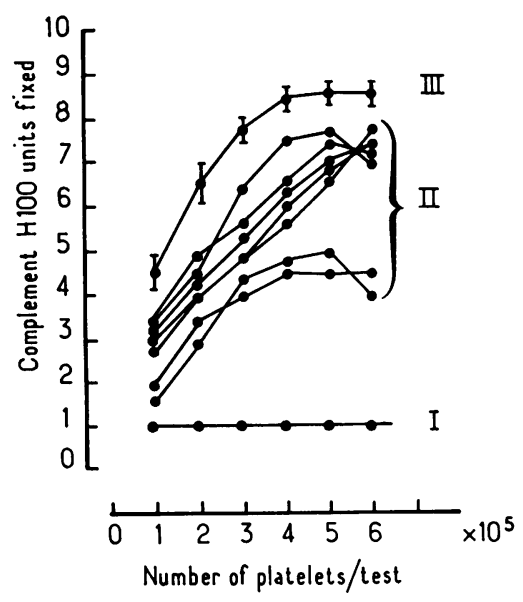

Figure 1 Curves of quantitative complement fixation on platelets with serum L. The maximum number of $\mathrm{CH} 100$ units fixed was noted for each quantity of platelets. (I). Platelets from eight thrombasthenic patients (identical results for each patient). (II). Platelets from seven heterozygous individuals. The two lower curves were highly suggestive of a single gene expression. (III). Platelets from 10 normal individuals (bars represent $1 \mathrm{SD}$ ). The fixation of one $\mathrm{C}$ unit observed with the serum alone was due to a weak anticomplementary activity in the serum.

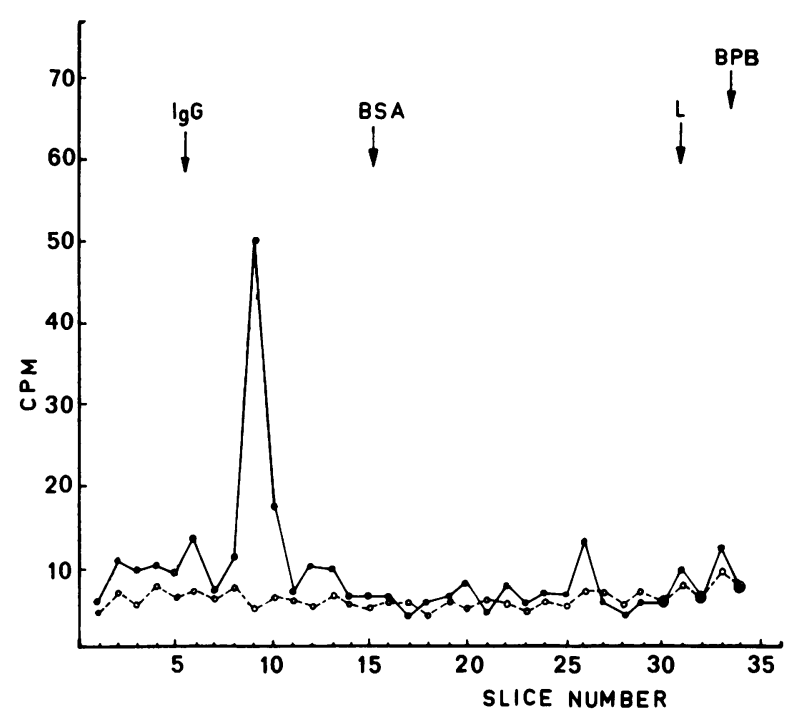

FIGURE 2 Electrophoresis in sodium dodecyl sulfate acrylamide gel of precipitates formed between $60 \mu \mathrm{l}$ of soluble platelet antigens and $20 \mu 1$ of eluate $\mathrm{L}(-\bullet)$ or 20 $\mu 1$ of normal serum $(\mathrm{O}-\mathrm{O})$ in the presence of an excess of rabbit antihuman IgG antibodies. The radioactivity peak corresponds to a protein of $120,000 \pm 5,000$ daltons. Molecular weight markers incorporated into the gel were human $\operatorname{IgG}(\operatorname{IgG})$, bovine serum albumin (BSA), and hen egg white lysozyme (L). BPB, bromophenol blue.

The molecular weight of the molecule bearing the antigenic determinant reacting with serum $\mathrm{L}$ was determined by Sephadex G-200 filtration. It was approximately $120,000 \pm 12,000$ no matter what method of preparing soluble antigens was used. In these studies the simultaneous estimation of the molecular weight of the HL-A molecule gave the expected value of 50,000 $\pm 12,000$ (15).

Using serum or eluate $\mathrm{L}$, indirect specific immunoprecipitation of soluble antigens labeled with iodine-125, extracted by the detergent Nonidet P-40 and electrophoresis on sodium dodecyl sulfate polyacrylamide gel, showed a single radioactive peak accounting for $1 \%$ of the total antigens labeled, thus corresponding to a molecule of $120,000 \pm 5,000$ (Fig. 2). The control, using normal serum, gave no peak.

ADP-induced aggregation of normal platelets was completely inhibited by eluate $L$ up to a dilution of $1: 20$. Thrombin, collagen, and epinephrine also inhibited aggregation but ristocetin did not.

\section{DISCUSSION}

The antiplatelet antibodies found in a polytransfused thrombasthenic patient were clearly different from the usual complement fixing platelet antibodies which are directed against HL-A or ABO antigens or, more rarely, against $\mathrm{Pl}^{\Delta 1}$ or $\mathrm{Pi}^{\mathrm{E1}}$ (9). A previous report (17) 
of shortened survival of $\mathrm{ABO}$ and HL-A matched platelets in another thrombasthenic patient may have suggested the existence of a similar antibody, but this could not be proved by in vitro experiments. The antibodies found in serum $\mathrm{L}$ recognized an antigenic determinant present on normal human, mouse, and dog platelets but clearly absent from those of other thrombasthenic patients.

A quantitative study of platelets from families afflicted with thrombasthenia indicated an intermediate amount of antigen in the parents and children of patients. Although this is an autosomal recessive disease, on clinical grounds the ability to distinguish between normal and heterozygous individuals in a thrombasthenic family may be of practical importance in spite of the low gene frequency of the thrombasthenic trait.

These findings strongly suggest that the antigenic determinant absent from thrombasthenic patients is born by a molecule involved in platelet aggregation. This hypothesis is supported by the fact that APDinduced aggregation of normal platelets is inhibited by eluate $\mathrm{L}$.

Isolated human platelet membranes have previously been shown to contain a heterogenous group of polypeptides of different classes of molecular weight ranging from 10,000 to 250,000 (18-20). Only a few of these membrane proteins have as yet been isolated, and their functional properties are still unknown.

The molecular weight of the molecule bearing the antigenic determinant under study was estimated by two different methods (Sephadex G-200 filtration of soluble membrane extracts and electrophoresis in sodium dodecyl sulfate polyacrylamide gel). It averages 120,000 . Inasmuch as a $10 \%$ acrylamide gel was used, the molecular weight estimation would not be inaccurate even if the antigen is a glycoprotein (21). This protein seems clearly to be different from the protein of 80,000 daltons (thrombosthenin) studied by Nachman and Ferris (22). Nurden and Caen's work (5) suggest that one of the three major glycoproteins in normal platelet extracts was missing from the platelets of three thrombasthenic patients. The molecular weight of this protein was approximately 135,000 .

Our data demonstrate that thrombasthenic patients have a molecular defect. It cannot be shown whether the gene products are indeed absent or merely nonfunctional, and further studies involving purification of the component from normal platelets are required to characterize its properties more fully.

\section{ACKNOWLEDGMENTS}

We would like to thank Dr. S. Levy for his help in coagulation studies and Miss A. M. Somerset for her help in the preparation of the manuscript.

\section{REFERENCES}

1. Braunsteiner, H., and F. Pakesch. 1956. Thrombocytoasthenia and thrombocytopathia. Old names and new diseases. Blood J. Hematol. 11: 965-976.

2. Hardisty, R. M., K. M. Dormandy, and R. A. Hutton. 1964. Thrombasthenia. Studies of three cases. Br. J. Haematol. 10: 371-387.

3. Caen, J. P., P. A. Castaldi, J. C. Leclerc, S. Inceman, M. J. Larrieu, M. Probst, and J. Bernard. 1966. Congenital bleeding disorders with long bleeding time and normal platelet count. I. Glanzmann's thrombasthenia (report of fifteen patients). Am. J. Med. 41: 4-26.

4. Nachman, R. L. 1966. Thrombasthenia: immunologic evidence of a platelet protein abnormality. J. Lab. Clin. Med. 67 : 411-419.

5. Nurden, A. T., and J. P. Caen. 1974. An abnormal platelet glycoprotein pattern in three cases of Glanzmann's thrombasthenia. Br. J. Haematol. 28: 253-260.

6. Colombani, J., J. D'Amaro, B. Gabb, G. Smith, and A. Svejgaard. 1971. International agreement on a microtechnique of platelet complement fixation. Transplant. Proc. 3: 121-126.

7. Colombani, J., and M. Colombani. 1973. Principles and application of a quantitative complement fixation microtechnique. In International Symposium of HL-A reagents. R. H. Regamey and J. V. Spärk, editors. Karger AG, Basel, Switzerland. 18: 89-92.

8. Colombani, J., M. Colombani, and J. Dausset. 1973. Non-complement-fixing IgM antibodies with anti-HLA2 specificity and blocking activity. Transplantation (Baltimore). 16: 257-260.

9. Shulman, N. R., V. J. Marder, M. C. Hiller, and E. M. Collier. 1964. Platelet and leucocyte isoantigens and their antibodies. Serologic, physiologic, and clinical studies. Prog. Hematol. 4 : 222-304.

10. Born, G. V. R. 1962. Aggregation of blood platelets by adenosine diphosphate and its reversal. Nature (Lond.). 194 : 927-929.

11. Marchesi, V. T., and E. P. Andrews. 1971. Glycoproteins : isolation from cell membranes with lithium diiodosalycilate. Science (Wash. D. C.). 174: 1247-1248.

12. Reisfeld, R. A., M. A. Pellegrino, and B. D. Kahan. 1971. Salt extraction of soluble HL-A antigens. Science (Wash. D. C.). 172: 1134-1136.

13. Schwartz, B. D., and S. G. Nathenson. 1971. Isolation of $\mathrm{H}-2$ alloantigens solubilized by the detergent NP-40. J. Immunol. 107 : 1363-1367.

14. Marchalonis, J. J. 1969. An enzymic method for the trace iodination of immunoglobulins and other proteins. Biochem. J. 113: 299-305.

15. Dautigny, A., I. Bernier, J. Colombani, and J. Jollès. 1973. Purification and characterization of HL-A antigens from human platelets, solubilized by the nonionic detergent NP-40. Biochim. Biophys. Acta. 298: 783-789.

16. Laemmli, U. K. 1970 . Cleavage of structural proteins during the assembly of the head of bacteriophage T4. Nature (Wash. D. C.). 227: 680-685.

17. Bucher, U., A. de Weck, H. Spengler, L. Tschopp, and H. Kummer. 1973. Platelet transfusions: shortened survival of HL-A-identical platelets and failure of in vitro detection of anti-platelet antibodies after multiple transfusions. Vox Sang. 25 : 187-192.

Molecular Defect in Thrombasthenic Platelets 
18. Nachman, R. L., and B. Ferris. 1970. Human platelet membrane protein. Biochemistry. 9: 200-205.

19. Pepper, D. S., and G. A. Jamieson. 1970. Isolation of a macroglycopeptide from human platelets. Biochemistry. 9: 3706-3713.

20. Phillips, D. R. 1972. Effect of trypsin on the exposed polypeptides and glycoproteins in the human platelet membranes. Biochemistry. 11: 4582-4588.
21. Segrest, J. P., R. L. Jackson, E. P. Andrews, and V. T. Marchesi. 1971. Human erythrocyte membrane glycoprotein: a re-evaluation of the molecular weight as determined by SDS polyacrylamide gel electrophoresis. Biochem. Biophys. Res. Commun. 44: 390-395.

22. Nachman, R. L., and B. Ferris. 1972. Studies on the proteins of human platelet membranes. J. Biol. Chem. $247: 4468-4475$. 